\title{
WATER POWER IN THE UNITED STATES
}

\author{
By M. O. Leighton,
}

Chief Hydrographer, United States Geological Survey, Washington, D. C.

The people of the United States must give up their leadership in the productive world when they shall have placed in use all their sources of cheap mechanical energy.

Present-day leadership in the productive world must be based on energy. This energy must, in the first place, be an inherent quality of the people and, in the second place, there must be an abundant external supply which the people can harness and subdue. Whatever amount of the one there may be, there can be no leadership of long standing without a fully proportional amount of the other. The converse is quite as true. The American people possess limitless inherent energy ; therefore their industrial progress must be dependent upon the amount of external power that they can command. This progress can continue up to a point at which the cheap power is all placed in use. Thereafter the best that our people can do is to hold fast. But such a condition is unstable. Some other people making skillful and energetic use of a larger amount of power would not only take the leadership but, in conformity with the scriptural "Parable of the Talents," they would by virtue of their larger possession take from our people that which they already have. It is a faithful saying that a halt in progress marks the beginning of a backward movement.

The finding out of what kind and of how much mechanical energy there is ready for use in this country is the first step in shaping our future industrial expectations. The process of the finding therefore becomes one of our most important matters of public duty. If our promised needs for mechanical energy bid fair in the near future to consume or to utilize all our sources of power, then will it be a part of wisdom to approach that crisis with our eyes open. On the other hand if our sources are so vast that the end may not be reached for many generations, then our problem is reduced to a wise selection of the best and most economical use of that which we have. 
Two main points should be borne in mind: First, that we shall make full use of the kind of power that will finally be the cheapest; second, that we shall be as miserly in the use of our sources of energy that become impoverished in the using as is consistent with final efficiency and purposeful results. The mere possession of great sources of mechanical energy will not insure industrial leadership. Each source must be properly harnessed. Having done this, it behooves us to have a care that we do not habitually burden our family driving horse with a load adapted to a percheron.

Leadership in the productive world may depend upon the wisdom with which the sources of mechanical energy are chosen, quite as much as upon the skill with which that energy is used.

As one generation follows another and leaves no gap between, so the methods and the tools of the one, being cheaper or more effective or less destructive than those of the other, gradually drive them from the field. It is necessary in the use of mechanical energy to choose that which is cheapest and most effective. It would be of little use for the people of one country to possess and to use a certain source of energy, be it ever so abundant, if that energy were not as efficient or were more costly than that used by the people of another country. Such a situation would merely suggest the comparison of two artisans, one of whom uses poor and the other good tools. If the people of this country persist in using a costly form of energy, which by the very use thereof hastens the final impoverishment of the available supply, they can not expect always to compete with the people of any other country who use a cheap and effective agent of mechanical power, which, moreover, is not impoverished.

The United States is using over $26,000,000$ horse power produced by fuel and principally by the use of coal in steam boilers. Utmost ingenuity has been practiced by the engineering profession in the improvement of methods of steam production and utilization. The cost of installing a steam plant is comparatively small-far less than the first cost of a water-power plant of similar capacity. Moreover, it is easy and convenient to set up a steam power unit well suited to the transient demands and there is a certain satisfaction in the completeness and independence that it affords. Until yesterday or the day before, the steam plant was practically the 
only agent of power that could be the resort except in unusual and often inconvenient localities. All of these as well as sundry other considerations developed in the power user the steam boiler habit. This was but natural. The man who sought to establish himself in a manufacturing business wished to place himself on a profitable operating basis at the earliest possible time. He chose the cheaper power installations as a first investment, trusting that the profits of the business would justify him, even though his subsequent expenses of maintenance were higher than they would have been with water power. In other words, he preferred a small immediate expenditure to a small ultimate one. The steam plant fairly met the conditions, but it has all been the result of surpassing ingenuity and adaptation.

There are being used in this country only about five and onehalf million horse powers developed by falling water. Especially in the earlier days do we fail to find anything like the degree of ingenuity in the adaptation of such power which we find in the use of steam. There is a good reason for this, which will be discussed later. That which it is desired to emphasize here is that, up to the day of electrical transmission, water power was used only where it was situated so conveniently and developed so cheaply that the economy was self-evident. Before the day of steam our manufacturing centers were located at water powers. After the development of the compound engine, power centers sprang up in the almost waterless plains. The industrial world went steam mad. What of the consequences?

There is no disposition to claim that the almost universal turn to steam was not based upon fundamental necessities. It was one of the reasons for our industrial advancement and it must ever mark an epoch in our civilization. But it was not without its detriment. The tide of industrial favor turned squarely away from water power. It was a dethroned monarch and few were those who gave it thought. Thus the steam habit became fixed, and so firmly does it hold sway that, even in this day of electrical transmission, the steam tide is not checked. Steam plants are installed in utter forgetfulness of waterpower possibilities. Such powers still await the engrossing attention that was in the earlier day bestowed on steam. In spite of all this, it is apparent to everyone who has examined into the situation that fuel power is more costly than water power. Therefore in persisting in the use of fuel power the people of the country have 
burdened themselves with an often needless tax. Such a tax must be a handicap. In the face of a world's progress, can we afford to carry a handicap? We are not the only progressive people on earth. There are other nations who will command our best efforts in the race, even if we are stripped for the fray. By turning to water power as their source of mechanical energy they will easily outproduce and under-sell us. It all rests on the wise selection of the cheapest source of energy; it is the parallel of the good and the poor tool.

Our stores of fuel are being consumed and the price thereof must increase.

The total amount of coal consumed in the United States from about 1814 to the close of the year 1908 is $7,279,734,143$ tons. The increase in coal consumption is shown by the following statement:
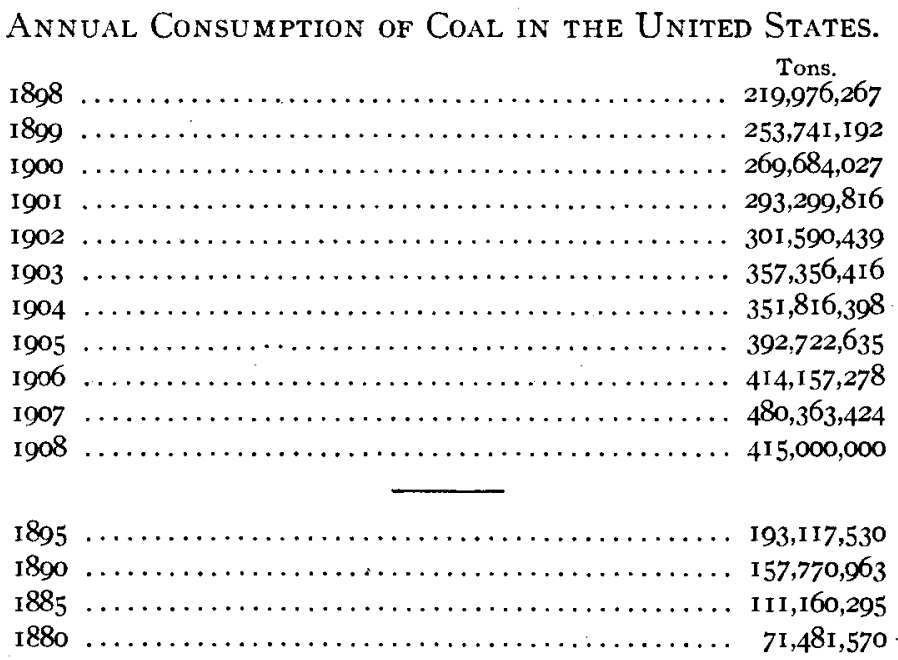

Our stores of coal have been well explored and those who know most about the situation say that, at our present rate of increase in consumption, all our coal will be gone before the middle of the next century, and some declare that the end will be seen during the present century. Now this may not seem important to the man who conceives that he has no duty beyond his day and generation, 
but he is mistaken even from his own standpoint. It is an inevitable natural law that whenever the supply of any commodity becomes reduced the price thereof must increase, and moreover the increase is progressive from the beginning of the impoverishment of that supply until the end. The coal supply and the price thereof form no exception to this law. 'The price of coal is lower to-day than it will be five years hence. The price of anthracite coal has increased until the limit has practically been reached, that is, so long as our bituminous coals remain at a price approximating the present market value, it will not be economical to pay more for anthracite coal than approximately the present market price. This is merely an economic adjustment between the thermal efficiency and the market price of the two kinds of coal, but it forcibly illustrates the fact that our demands upon the store of anthracite coal have already impoverished it to an extent that nearly drives it from the market at the present time.

As the cost of coal is the chief item in the cost of steam power, it follows that an increase in the price of coal must mean an increase in the cost of steam power, which will widen the margin of cost of steam over water power. The handicap imposed by excessive cost of steam power is a growing one. The greater our progress under steam power, the greater must be the unit price that we pay for such progress. The right way to meet this condition is to lessen the demand. This can best be done by supplying the people with mechanical energy from running streams.

Only a certain part of the coal that we consume is used for power generation. It is inevitable that for a long time in the future coal or similar fuel will be needed for mere heating purposes. Therefore there is a good reason for saving our coal supply, even though there is promise that it may not in the near future be needed for power generation. Although at the present time our methods of converting electrical energy into heat are too wasteful to be adopted on any large or general scale, we may reasonably expect that continued improvements in our methods of conversion will make a progressive reduction in our dependence on the use of fuel for heating purposes. But, even if our methods are improved faster than we may reasonably expect at the present time, it will be several centuries before all our use for fuel will be supplanted by another source of energy. It will be of interest to consider what proportion 
of the coal consumed in the year 1908 might have been saved had there been in this country a development of water power sufficient to supply the greatest reasonable and possible demand, due regard being given to considerations of market and cost of water-power development. Such a statement must be based on our present limits of electrical transmission and conversion and, broadly speaking, such limits must be confined to the use of water power for light and mechanical energy, with an efficiency limit of transmission at I5O miles.

At least one-third of the coal now used in the United States could be saved by the wise and considerate development of water power.

There are in use in the United States somewhat more than $26,000,000$ horse powers produced from fuel, principally in the form of steam power. Not all of this power could be supplied from water-power plants. The reason for this is that there are many great steam-power centers located at points remote from great water powers. To supply the large demands at those points, it would be necessary to transmit electrical energy over greater distances than can be done efficiently at present. The longest transmission in the United States is 220 miles, but this is accomplished only with a sacrifice of economy. This power station is one of a connected chain from which energy is supplied to several centers of utilization. There are times when the demand at the most remote point in the system is greater than can be supplied by the near-by stations and it becomes necessary to make up the deficiencies by transmitting from the farthermost station, 220 miles distant. In other words, this transmission is the resort of necessity rather than the practice of economy. Those most familiar with the practical side of electric power transmission testify that under present conditions the line losses increase disproportionately beyond a distance of about IOO miles. Of course, longer transmission is fairly common and not without profit to the producer; but, on the other hand, the shorter transmission is far more profitable per kilowatt hour.

The conditions above stated would apply with force in case it were attempted to substitute electric power for all our present steam plants. The City of New York, for example, is probably the 
greatest center of mechanical power consumption in the United States, if not in the world. Water powers situated within the present limits of efficient transmission to this city would not supply more than a small part of the entire demand. This being the case, it is doubtful if it would pay to try to utilize that which might be supplied. Such condition will, of course, be corrected in the future. Improvements in the efficiency of wire transmission will surely be marle. It appears to the author, after taking a general view of the entire country, that about eighty per cent. of the steam power used could be replaced by water power. Let us assume, for the sake of being conservative, that the amount is seventy-five per cent. This means that there are $19,500,000$ horse powers, which presumably may be produced by water power. It is not meant by this that every unit included in this great substitution could immediately be put on a paying basis-far from it. The ultimate benefit must be derived from the system as a whole. The case resembles that of a great railroad system; some of the branches are operated at a loss and others at an immense profit. The algebraic sum of profits and losses for the whole system determines the ultimate profits. So in the present discussion we are considering water power from the broad standpoint of essential public economy. The subject is so great that the gimlet-hole view must be incomplete. The progress or poverty of any particular plant is not of immediate importance.

It is not an easy task to determine the average amount of coal used to produce a horse power throughout the year. Boilers and engines throughout the United States differ widely in efficiency. There is a similar variation in the heat-producing quality of our coals. Some of the power produced in steam plants is used only ten hours each day, and during the remaining fourteen hours little coal is used. Otlier plants are in practically constant operation. Therefore any estimate of the average consumption of coal per horse-power-year for the whole country must be subject to errors of individual judgment. All the facts having been considered, the author believes that ten tons per horse-power-year is fair and reasonable, and he will use this as the factor. Any person who believes another factor would be more suitable may change the following estimate accordingly. The $19,500,000$ steam horse powers above named must have required the burning of $195,000,000$ tons of coal in 1908 , which is about forty-seven per cent. of our total production 
for that year. This figure presents a fair idea of the amount of coal that might be saved by the substitution of water power under present limits of efficiency in electric conversion and transmission. What do the people of the country pay for the privilege of using their coal in this manner?

The people of the United States are paying a high price for the privilege of impoverishing their coal resources.

We must now face the task of estimating how much more steam power costs than water power. Of course, the cost varies with the price of coal and with the ease with which water power may be developed in various parts of the country. Some water powers may be improved and operated at small cost, while others are so expensive that they can not be profitably built and operated at the present market price of power. This market price varies also. In the great Northwest, for example, the price of coal is high, while water powers, especially in Columbia River basin, may, as a rule, be established at a relatively low cost. On the other hand, in a coal-mining region, where coal can be purchased at a nominal price, the water power than can compete with a steam-power plant must be of unusual cheapness and efficiency. The conditions vary so widely that the best way to arrive at some basis of estimate is to select some area which fairly represents average conditions.

In the area so chosen coal should be comparatively cheap and water abundant. The author believes that such an area is defined by the State of New York. It is situated so near the Pennsylvania coal fields as to make the price of coal somewhat below the average. On the other hand, New York is bountifully supplied with waterpower privileges. Therefore the relative cost of the two kinds of power in New York ought to afford a good as well as a very conservative factor for the entire country. The New York State Water Supply Commission, in making its third annual report in I908, gave careful study to the relative advantage of water power over steam power and reported that "at a low estimate the advantage of water over steam power is at least $\$ 12.00$ per horse power per year." Note that this is a "low estimate" for New York State, and note further that in this state steam power must be relatively cheap. Therefore it seems hardly possible that if this factor of $\$ 12.00$ be 
used for the whole country, the total will be too high. Applied to the $19,500,000 \mathrm{H}$. P. above referred to, there is given the stupendous annual charge of $\$ 234,000,000$ annually, which may be regarded as a penalty for using steam power. Supposing this amount were deposited annually to create a sinking fund, can there be any doubt that the principal sum would be sufficient to develop the equivalent amount of water power and also to pay the damages arising from the abandonment of steam plants as fast as they were worn out in service?

The menace to American industrial leadership is already on the horizon.

It has been stated that leadership in the productive world depends upon a wise choice of the source of mechanical energy to be utilized in such production. It ought to be clear that we, as a people, can not sustain this leadership if another people choose to pursue a policy that will place at the disposal of the manufacturing world a cheaper power than that which we supply. It behooves us to look about and see whether or not there is any indication that such a policy is present or prospective.

The situation in Switzerland ${ }^{1}$ is not without its menace. The people there have awakened to the fact that, whereas their scenery is a great resource, greater possibilities lie in their water powers. They are developing these powers, with the professed purpose of attracting within their boundaries as large a number of industries as they can supply with motive power. Great plateaus and benches previously given over to agriculture are the prospective sites for such manufacturing plants. So wide of scope is the plan that those who revere the scenic beauties of Switzerland are becoming disturbed over the promised impairment thereof. The whole plan is one of national encouragement of industries. Is there anyone in the United States so confident of this country's industrial leadership as to assert that the wholesale development of those large and cheap powers in Switzerland will not seriously affect our status in the productive world? Trade and production are entirely cosmopolitan. The cheapest sources of energy are going to be used without refer-

\footnotetext{
'See paper in this volume on "Federal Control of Water Power in Switzerland," by Treadwell Cleveland, Jr.
} 
ence to any particular flag if they are located in a region convenient to market. There could be found no point more accessible to all the great markets of Europe than the Republic of Switzerland. Nor is Switzerland alone in this practical advantage.

France is making amazing strides in water-power matters and the appreciation of the public duty in this respect appears to be more acutely felt there than in almost any other country. There is proper recognition of the fact that electric transmission of water power has introduced a new and forceful element into the political economy of the Republic. Whereas, before transmission, water power was a local matter, appurtenant to the particular site at which it was located, it has become a matter of general and special utility and should be so treated in the administration of government. French law relative to water-power development has received careful consideration during the past few years, and new concepts relative to the rights of the state have been adopted.

The first proposed reform consists of the granting of concessions for the development of water power, in the same manner as concessions are granted for public or quasi-public works, these concessions being limited to a specified time and to a specified amount of power. The principles proposed as a basis for this reform are: first, that all the various uses of water power must be facilitated and encouraged simultaneously, because it is of the greatest advantage to distribute the power produced among the greatest possible number of uses; second, that engineers and representatives of all kinds of interests must be encouraged to make studies and propositions as to combinations and projects of every nature relative to the best uses of water power; third, that the power of concession must belong to the state, which alone is able to combine all available information and to settle difficulties arising among opposing interests, the state in this case being the central government of the Republic. This power of concession is to be exercised irrespective of all business and financial prejudice, in the sole effort to derive the greatest possible amount of benefit. In every case in which there is no general public interest that would be daniaged thereby, and only in such case, such concession shall be granted in the following order of preference: to the province; to the county; to the private company. The fourth principle is that the term of concession shall be as limited as possible in order that mistakes or defects may from 
time to time be corrected and that changes may be made to conform to modifications in conditions.

The broad proposal briefly outlined above indicates merely that the Government of France is entering upon a campaign of encouragement and development of water powers, with the sole purpose in view of making the greatest possible use of this, its most important source of mechanical energy. It is significant that so broad a principle of public control should have been proposed and it is to be assumed that the proposal was the result of careful consideration, supplemented by the ripe experience of the famous hydraulicians, both past and present, of that country.

Germany, Austria, Italy, Sweden and Norway do not lag behind France and Switzerland in making a bid for industrial leadership through the agency of water power. Not long since Norway diverted from the United States to its own borders a great manufacturing plant, the product of which is one of the most necessary commodities in modern trade, necessary in peace and indispensable in war. The sources from which the world is now supplied with that product are failing and the process of this great company will eliminate those sources from the market, whether they fail within a decade or a century. The possession of that industry within our borders would certainly have been of strategic importance, but because public policy in the encouragement of water-power development in the United States is not as favorable as that in Norway, the industry located there. Having utilized the sites that were ceded to it by the Norwegian Government, this company is now seeking another location on which it is proposed to make a larger water-power development than has ever been comprised in a single unit or group of units. There are in the United States numerous sites at which this demand for power could be supplied, but the same conditions prevail here now as prevailed at the time of selecting the first location. European countries, knowing the strategic value of the plant in time of war, are offering inducements and concessions. The company, for various reasons, not the least of which is patriotism, would prefer to locate in the United States; but it finds among the people here no disposition to meet the conditions imposed by the situation, and at the present writing it looks as though the plant would be located in either Germany, Switzerland or France. If our people do not take advantage of this opportunity, 
it is probable that at some time in the future the United States will be obliged to buy the most necessary element in national defence from an unfriendly power or through a mediator. There are real difficulties in the way of securing proper concessions to meet such an emergency as this. The country that has adopted a policy will always have the advantage of a country like ours, which has no policy save that of tolerance and license of the greed of individuals.

There is more than enough water power in the United States to fulfil every want that may reasonably be expected to arise in many generations.

When we sum up our power resources and try to find out how long they will serve our future needs, we must look at the matter from a viewpoint different from that taken by the promoter of toclay. He is seeking an investment that will return a profit, and the elements that enter into his considerations are immediate cost and immediate market. It is not pleasing to him to invest in a plant that promises remote profits, but he seeks the opportune combination of demand and supply. We, on the other hand, must have in mind the broader subject of public necessity and economy. Therefore, when we say that our available water power is so much, it should be understood that a part of that amount is not suited for immediate use, but will become useful when our demands have increased to a point at which the high cost of installation is warranted. Some day in the future, the water-power privileges that we now pass without a moment's consideration will be profitably utilized. With this principle in mind, let us estimate the extent of our power resources.

No complete survey has ever been made of the water powers of the United States. In some parts, the facts are well known; in others, we have only approximate data. Yet that which is hereinafter set down is accurate enough. The power afforded by any river may be stated in several ways, each of which is subject to interpretation. Rivers fluctuate in flow, and it follows that the power must vary according to the fluctuation. Therefore in stating the available power it is necessary to give the stage of the river at which the stated amount may be produced. It should be plain that the most useful power is that which will be continuous throughout the dryest year, and this is the amount that will be developed by 
the lowest flow. The usual expressions for the energy so produced are "minimum power" or "primary power."

Whenever the river is running above the minimum flow, the power that it will develop is increased. Usually, the period of minimum flow is short, sometimes continuing for only a week or two, and seldom does it occur for more than two or three months in humid regions. Therefore, during the greater part of the year the river will produce more than the primary power. This power in excess of the primary may often be used for purposes that do not require power during the entire year. When, for example, a manufacturing plant which runs only a part of the year can be regulated in operation so that the periods of high water may be utilized, then the use of the power in excess of the primary is of great value. There are many other conditions and circumstances under which excess power may be used to advantage. The power in excess of the primary is usually termed "secondary power."

One of the important studies previous to the construction of power plants is that of the limit to which secondary power can be economically developed. In some parts of the country it is profitable to install wheels and appurtenances to develop power up to that which will be produced by the minimum flow for the four months of highest water in the year; in other parts it is necessary to develop to the minimum for the highest eight or ten months in order to warrant the expenditure. The market for such power is the deciding factor. A fair average limit of profitable installation for the entire country is represented by the power corresponding to the minimum flow for the six highest months in the year; this factor has been used in the following schedule.

The third basis for power statement is the "total power with conservation," that is, the power which may be developed if the upland floods are stored in reservoirs and held until needed during dry seasons. It is plain that such a procedure will greatly increase the low-water flow and correspondingly increase the primary power available. Such a process is the highest development of a river for use in any capacity. The primary power so developed is the maximum that the river will furnish.

In developing the following figures consideration has been given to many of the conditions that prescribe the limits of power production on our rivers. Especially has the slope of the stream chan- 
nels been scrutinized. The theoretical energy developed by a river is that which would be produced by the average amount of water that it carries if it should fall a perpendicular distance equal to the fall of the river from source to mouth. It has not been assumed that, even under ideal conditions of market, all theoretical power will ever be commercially available. The flatter portions of river channels can never be profitably developed and they have not been included in the schedule. In all cases the actually measured fall has been reduced ten per cent. in the computations. A further reduction of ten per cent. has been made to compensate for wheel efficiency. It is recognized that ninety per cent. is too high a wheel efficiency to be used in calculations of power at the present time, seventy-five or eighty per cent. being the usual installation maximum. Here again, it should be recalled that we are computing for future conditions as well as present ones and it may confidently be expected that, with the improvement of turbines, a greater percentage of the theoretical power will be realized on the shaft. We may expect before long to secure a ninety per cent. efficiency.

The rivers have been divided into sections of varying length, determined by channel slope, and the fall and flow of each section have been obtained from the best available sources of information. The records of stream flow collected by the Water Resources Branch of the Geological Survey have almost uniformly been the only available resort, although acknowledgments should be made to the State Water Supply Commissions of New York and Pennsylvania, the State Engineers of New York, Colorado, California, Oregon and Nebraska, the Territorial Engineer of New Mexico, the State Geological Surveys of Maine, New Jersey, North Carolina, Virginia, Georgia and Wisconsin, and to the various other bodies and individuals, public and private, who in the past have maintained measurements in co-operation with the United States Geological Survey, or independently. Use has also been made of certain river gauge records of the United States Weather Bureau and the Corps of Engineers, U. S. A.

In the actual management of storage the waters are released according as needed and they must be distributed as closely as possible according to the severity and length of the dry season. Such distribution will vary each year according to the climatological conditions governing river discharge. Some assumption has been neces- 
sary and it is believed, from the experience gained in the study of rivers throughout the country, that it will be fair and conservative to assume that if in present computations of the amount of power with conservation any given storage be considered as drawn upon uniformly during six months of the year and the natural flow from the unconserved areas be considered as sufficient to maintain at least an equal flow during the remaining six months, the results will not depart too widely from the actual conditions as regards total power.

The following schedule is the result of the process above outlined. The results do not include the State of Pennsylvania, figures for which had not been furnished up to the date of this report.

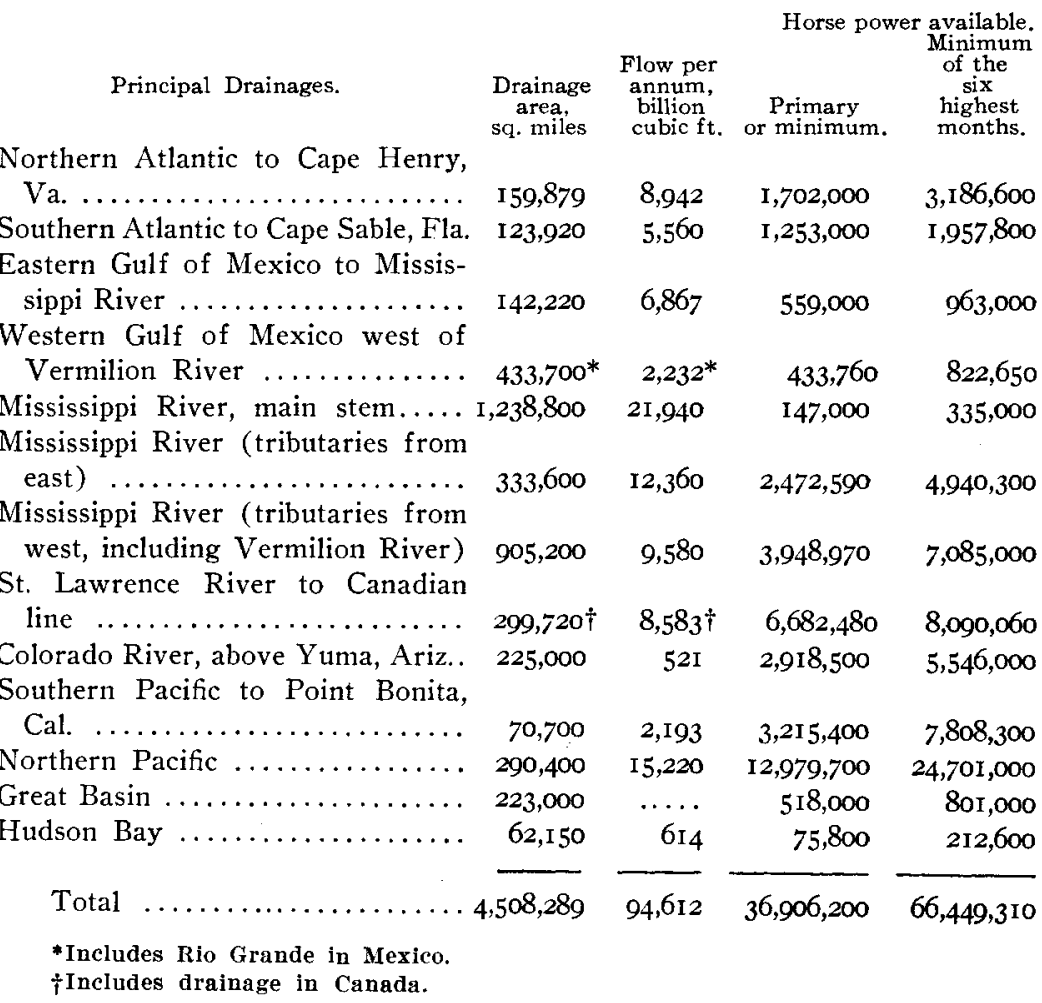

The remarkable feature of the foregoing table is the indicated amount of available water power in the Northern Pacific drainage. This area includes all the Pacific Coast streams north of Point 
Bonita or Golden Gate. It includes the Sacramento River and its highland tributaries, also the Columbia River. The latter is by far the greatest water-power stream on the American continent. Few people living within the basin have any adequate idea of the resources there, and the remainder of the people of the country are practically ignorant even of the general facts. In a country as great as that of the United States and in which water powers are so abundant, it is astonishing to find that one-third of the power resources are existent in this proportionately small area.

The drainage next in size from the standpoint of water power is that of the St. Lawrence. It is needless to state that the power resources at Niagara, which include the cataract and rapids below, add materially to the total figure. Although in the foregoing table the drainage area and the flow are given complete, the water-power figures, outside of Niagara and the St. Lawrence itself, include only those powers within the territory of the United States. The total power afforded by Niagara River will never be utilized unless at some time in the future there is a demand for mechanical energy that transcends other considerations. Steps have already been taken by the United States and similar action is promised by the Dominion Government, under which a restriction is placed on the production of power so that the scenic beauty of the falls will not be destroyed. However praiseworthy this policy may be, it will certainly give way if at any time in the future necessity demands that all the Niagara power be placed in productive use. Of course, the contingency is remote-let us hope that it may never materialize.

The other great areas in which enormous power is available are the eastern and western slopes of the Appalachian Mountains, the eastern slope of the Rocky Mountains and Colorado River basin.

An endeavor has been made to estimate the power that might be produced if all storage facilities that were practicably available were developed. Topographic surveys on many of the basins make it possible to give a fairly close estimate; but, inasmuch as threefourths of the country has not been surveyed in this way, the estimates for that area must be approximate. There are two methods by which such an estimate can be made. In the first, it is necessary to determine the power with conservation in those portions of the country covered by adequate surveys, and then to assume that if the amount so secured represents one-fourth of our total area the 
total power must be approximately four times that amount. An examination of the facts will readily show that the amount so obtained will be too small. It is apparent from a review of the index map showing the areas covered by topographic surveys that a fairly large proportion, probably one-third, comprises country in which there are no feasible reservoir sites or in which they are uncommon in occurrence. Such portions include large parts of the Dakotas, Nebraska, Kansas, Oklahoma, Texas and Louisiana, together with great areas on the Atlantic and Pacific coastal plains. Therefore to increase the total available water power, from storage that may be computed on surveyed portions, by the ratio of total surveyed area to the area of the entire country would hardly do justice to the situation. Nevertheless, the figures are here presented.

It is found that the total power with conservation available in the surveyed portions is about $53,000,000 \mathrm{H}$. P. If this be considered as one-fourth, to correspond with the proportion of the country surveyed, the total power of the country, with practicable maximum storage, will be about 212,000,000 H. P.

The second method involves detailed study of the physiographic features of the country. The topographic surveys, while they cover only one-fourth of the total area of the country, have nevertheless been prosecuted in all sections and on all types of drainage area. If it is found, for example, that over a certain portion of the Colorado basin topographic surveys reveal a certain factor of storage, then it will be fair to assume that in every portion of that basin of the same physiographic type the same factor will roughly apply. This process has been employed for the whole country, and while the results are by no means sufficient for working estimates, they do nevertheless establish a fairly definite and reasonable limit. By using this method, there is afforded a grand total of $230,800,000$ H. P. This figure agrees so closely with that obtained by the first method that both figures are worthy of some confidence.

In any case, it will be fair to assume that, when all practicable storage sites are utilized and the water is properly applied, there will be eventually developed in the country a total power equivalent to at least $200,000,000 \mathrm{H}$. P.

No one can fix the date at which our people will use all this power. There are involved too many uncertain factors, the potency of which is either totally unknown or can merely be approximated. 
One who attempts to fix any precise or even approximate date will encounter the following difficulties.

First :-About eighty per cent. of the power used at the present time is produced from fuel. This percentage will decrease in the future, until the high cost of fuel will finally drive fuel power out of the market. Therefore, in summing up our future power utilization we may assume that all the power now and hereafter generated from fuel may be disregarded, for it will all finally be displaced by water power. The current increase in the use of fuel power is enormous and must continue for several decades at least. The great water-power developments of the next quarter century will be designed to supply mechanical energy to new markets in regions and places now unsupplied rather than to take the place of steam plants already installed. No one expects to see in the near future any actual decrease in the amount of steam power utilized unless, perchance, by some happy combination of events there should be brought about in the minds of our people a realization of things as they ought to be. Few men, in this generation at least, are possessed of sufficient altruistic instincts to induce them to give up their steam plants for the sake of the ultimate conservation of our coal resources. But even if this were not so, there would still be enormous utilization of coal. There are great centers of power utilization which, under the present limits of electrical transmission and conversion, can not be served by water power because they are situated too far from water-power sites. Therefore fuel power is necessary and will be utilized until electrical transmission has been made more efficient. All of this brings a fluctuating factor into the prediction concerning the sufficiency of our water powers in future years. There is no escape from a broad generalization in this matter.

Second:-It is unsafe to estimate the future demand for power from past utilization. The increase in the amount of power used for manufacturing purposes during the decade $1870-1880$ was fortyeight per cent. During the next decade it was seventy-four per cent. From I890 to I900 it was seventy-five per cent., while in the year I9Io the increase over that of I90o promises to be about eighty-five per cent. There is an increasing rate of increase in the utilization of power at the present time, but this can not always continue. While it may be that the actual amount of power in use 
will increase with each decade and that each decade's actual increase will be greater than that of the preceding, the percentage increase must, after a while, be less each decade. Just what this rate of decrease will be can not be foretold, for it is dependent upon so many changes in methods and production that it, too, must be largely generalized.

Third:-By way of partial compensation for the growing demand upon our power resources, there is the assured increase in efficiency with which that power is used. This is merely another way of saying that we shall accomplish more in the future with one horse power than we can to-day. The losses of potential power between the falling water and the application of that power, after transmission, transformation, etc., to productive work are great, but not as great as they were in years past. This improvement will continue, but no one knows how fast, and therefore another uncertain element enters into any estimate of the sufficiency of our water power resources. If in the use of our $200,000,000 \mathrm{H}$. P. we reduce the losses in efficiency from forty per cent. to ten per cent., the effect will be the same as though $60,000,000 \mathrm{H}$. P. were added to our ultimate resources.

All we know to-day is that according to our best calculations we have of available water power in the United States somewhat more than seven times our present total power utilization. Considering the matter broadly, with the above fluctuating factors in view, as well as many others not here discussed, it seems safe to predict that our water power will be sufficient for our needs for at least seven generations hence.

The water power plants in the United States make productive use of only five and one-half million horse pozers, an amount zehich is less than one-fortieth of that ultimately available.

The following table contains a summary of the number of water-power wheels and the horse power generated in each of the states of the Union. The figures are the result of a census made during the year 1908 by the United States Census Bureau. It is probable that they are not complete; yet all the important plants are included and it is certain that the missing data form so small a proportion of the total that these results can be accepted as substantially correct. 
State.

New York

California

Maine

Pennsylvania

Massachusetts

Oregon

Wisconsin

South Carolina

Michigan

New Hampshire

Vermont

Georgia

North Carolina

Alabama

Minnesota

Montana

Washington

Connecticut

Virginia

Tennessee

Colorado

Idaho

Utah

Illinois

New Jersey

Rhode Island

Ohio

Indiana

Maryland

Nevada

West Virginia

Kansas

Iowa

Alaska

Arizona

Kentucky

Nebraska

South Dakota

Missouri

Texas

Delaware

Mississippi

Arkansas

Florida

Wyoming

Oklahoma
Wheels. H. P.

$6,513 \quad 885,862$

I,070 466,774

$2,797 \quad 343,096$

$5,596 \quad 290,990$

$2,749 \quad 260,182$

$590 \quad 231,379$

I,667 220,916

I,30I 207,242

I,498 205,019

I,799 I83,I67

$2,018 \quad 170,276$

$\begin{array}{ll}2,314 & 166,587\end{array}$

$\begin{array}{ll}3,975 & 162,284\end{array}$

I,804 I6I,694

$531 \quad 152,380$

$204 \quad 148,052$

475. 147,041

I,546 II 18,145

3,0II 100,1 23

$2,160 \quad 95,060$

$353 \quad 78,878$

$285 \quad 78,743$

$260 \quad 64,265$

$4 \mathrm{I3} \quad 5 \mathrm{O}, \mathrm{II} 6$

90238,011

$387 \quad 37,165$

$873 \quad 34,840$

$495 \quad 29,153$

$694 \quad 21,715$

$39 \quad 20,577$

$672 \quad 20,500$

$184 \quad \mathrm{I} 8,606$

$46 \mathrm{I} \quad \mathrm{I7,304}$

I06 17,289

$37 \mathrm{I} 6,855$

$834 \quad \mathrm{I} 4, \mathrm{I} 56$

$227 \quad \mathrm{I} 2,792$

68 I I,I I2

$397 \quad 10,107$

$195 \quad 9,966$

$277 \quad 7,976$

$336 \quad 7,922$

$255 \quad 5,868$

$207 \quad 4,539$

$66 \quad 3,855$

$29 \quad 2,994$ 


\begin{tabular}{|c|c|c|}
\hline$\ldots \ldots \ldots \ldots \ldots \ldots \ldots$ & $\begin{array}{l}\text { Wheels. } \\
56\end{array}$ & $\begin{array}{l}\text { H. P. } \\
2,3 \text { IO }\end{array}$ \\
\hline Louisiana $\ldots \ldots \ldots \ldots \ldots \ldots \ldots \ldots \ldots \ldots \ldots \ldots \ldots \ldots \ldots$ & 79 & $\mathrm{I}, \mathrm{I} 84$ \\
\hline District of Columbia $\ldots \ldots \ldots \ldots \ldots \ldots \ldots$ & 6 & $I, \infty \infty$ \\
\hline 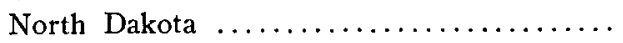 & I6 & 6I3 \\
\hline
\end{tabular}

The above results are shown by general drainage divisions of the country as follows:

\begin{tabular}{|c|c|c|}
\hline Division of the United States. & Wheels. & H. P. \\
\hline Northern Atlantic ....... & $2 \mathrm{I}, 864$ & $1,746,303$ \\
\hline 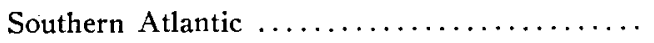 & 5,938 & 459,652 \\
\hline Gulf of Mexico: & & \\
\hline Eastern $\ldots \ldots \ldots \ldots \ldots \ldots \ldots \ldots \ldots$ & 3,342 & I 39,758 \\
\hline Western $\ldots \ldots \ldots \ldots \ldots \ldots \ldots \ldots \ldots$ & 258 & $12,07 \mathrm{I}$ \\
\hline Mississippi River : & & \\
\hline Tributaries from east $\ldots \ldots \ldots \ldots \ldots \ldots$ & 8,959 & 537,080 \\
\hline Tributaries from west & 2,385 & 331,739 \\
\hline St. Lawrence River ..... & 6,896 & $1,018,283$ \\
\hline Colorado River $\ldots \ldots \ldots \ldots \ldots \ldots \ldots \ldots$ & 285 & 74,428 \\
\hline Southern Pacific ... & 822 & 423,707 \\
\hline Northern Pacific $\ldots \ldots \ldots \ldots \ldots \ldots \ldots \ldots$ & 1,659 & 489,454 \\
\hline Interior Drainage $\ldots \ldots \ldots \ldots \ldots \ldots \ldots \ldots$ & 353 & I I 5,944 \\
\hline Arctic Ocean $\ldots \ldots \ldots \ldots \ldots \ldots \ldots \ldots \ldots \ldots \ldots \ldots$ & 66 & 8,261 \\
\hline & & 356 \\
\hline
\end{tabular}

Some interesting facts are shown by the above. The total development in the country is $5,356,680 \mathrm{H}$. P. over 52,827 wheels, or an average development per wheel of about $100 \mathrm{H}$. P. In the Northern Atlantic Division there has been a greater water-power development than in any other, the total installation being $1,746,303$ H. P. The only other division that approaches the Northern Atlantic in development is that covering the drainage area of the St. Lawrence, including the Great Lakes, where there has been a developmént of $1,018,283 \mathrm{H}$. P.

The great power development in the Northern Atlantic Division began at an earlier period than in any other portion of the country. New England and the Middle Atlantic States are and have been the important manufacturing centers of the country, largely by reason of the impetus imparted early in our history by the abund- 
ance of good water powers. Comparisons of wheel capacities installed in various parts of the country are interesting. While the total figures show that the average power per wheel is about 100 H. P., the units in the various districts vary as follows:

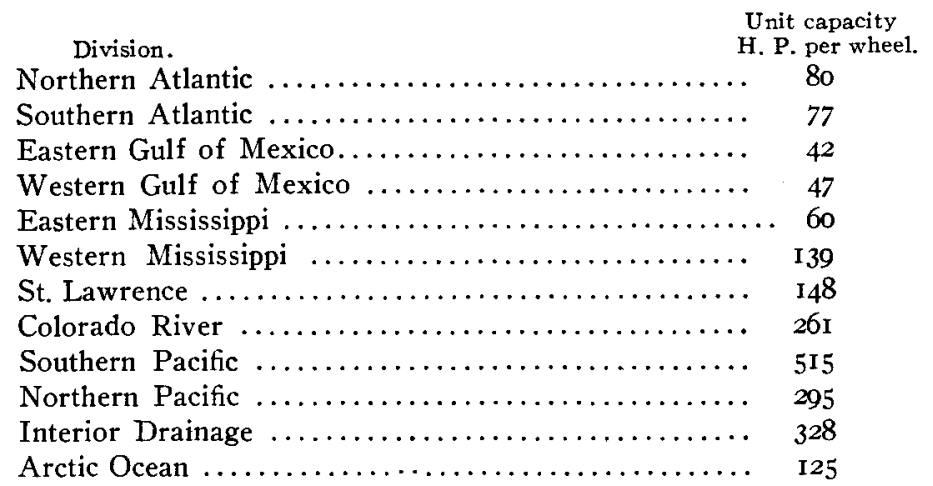

The large number and small capacity of wheels in the eastern part of the country as compared with the smaller number and larger capacity in the western portions, including especially the rivers draining from the Rocky Mountains and the Sierras, may be explained: First, by the fact that in the eastern and central portions of the country the power privileges are of smaller capacity; and second, by the fact that in the eastern portions of the country a large number of the powers were installed at an early date, when small units were common. More recent practice has involved the establishment of larger units, and, as the western installations are all recent, this practice, taken together with the existence of the larger power privileges, gives the result that might be expected from a general survey of the situation.

The first table shows that New York State has the largest water-power development, the total being $885,862 \mathrm{H}$. P. It is proper to add that the Niagara powers on the New York side assist largely in increasing this figure. The second state in water-power development is California, the total development being $466,774 \mathrm{H}$. P. over I070 wheels, or a unit installation of about $436 \mathrm{H}$. P. Water-power development in California is comparatively recent. The third state is Maine, with $343,096 \mathrm{H}$. P. over 2797 wheels, or an average of about $123 \mathrm{H}$. P. per wheel. 
Among the other interesting points is the fact that, although the Northern Pacific division can be made to furnish about onethird of the total minimum horse power of the country, there is at the present time a development of only $450,000 \mathrm{H}$. P., which indicates clearly that the most fertile field for power development remaining in the United States is this northwestern country.

Census returns show that, out of a total of $3^{1,537}$ powers reported, 602 are of capacity of 1000 H. P. or more. Recent progress in water-power development has been marked by great installations. In former years the aggregate water-power utilized in the country was made up largely of small units which, while useful for local purposes and worthy of development, are not relatively important in the great question of power economics. The following summary gives the distribution of the powers of Iooo H. P. and greater capacity, and it shows clearly that what was formerly believed to be an uncommonly great installation must now be considered a comparatively small one.

Capacity Distribution of Powers of $1,000 \mathrm{H}$. P. and More.

\begin{tabular}{|c|c|c|c|c|c|c|c|c|}
\hline $\begin{array}{c}I, 000 \\
\text { to }\end{array}$ & $\begin{array}{c}5,000 \\
\text { to }\end{array}$ & $\begin{array}{c}10,000 \\
\text { to }\end{array}$ & $\begin{array}{c}\text { I5,000 } \\
\text { to }\end{array}$ & $\begin{array}{c}20,000 \\
\text { to }\end{array}$ & $\begin{array}{l}25,000 \\
\text { to }\end{array}$ & $\begin{array}{l}40,000 \\
\text { to }\end{array}$ & $\begin{array}{c}60,000 \\
\text { to }\end{array}$ & $\begin{array}{l}\text { 100,000 Total } \\
\text { and number }\end{array}$ \\
\hline 000 & 10,000 & 15,000 & 20,000 & 25,000 & 40,000 & 60,000 & 100,000 & over. of powers. \\
\hline 459 & 65 & 27 & 13 & I7 & II & 4 & 3 & 602 \\
\hline
\end{tabular}

Brief descriptions of typical water-power plants, including statements relative to their organization, field of application, etc., will now be given. Obviously, it will be impossible to enter upon a detailed description of the structural and mechanical features of the various plants. This, in itself, would require more space than has been allotted to the present paper. The best that can be done is to outline the most noteworthy features, which typify the various situations under which power plants are developed and operated.

The water power available at any privilege depends principally upon two factors: First, the amount of fall or the hydrostatic head on the wheels; second, the amount of water that can be turned over the wheels. Water powers developed in the United States represent all sorts of combinations of fall and flow, the particular type depending on the natural conditions at the various sites. In the earlier powers in New England and New York, for example, the static head is usually low and to develop a great amount of power it is 
necessary to discharge a large volume of water upon properly designed wheels. In many of the more modern plants of the West, where only a small amount of water is available, there is a great fall. As a result we may have in one place a plant developing, say, Io,00o H. P. with a fall of anywhere from twenty to forty feet, and in another place a plant of the same capacity with a fall of I000, I 500 or 2000 feet. It is obvious that in the one case the lack of fall is compensated by the great volume of water and in the other case the converse conditions prevail. So far as the usefulness of the energy is concerned, it makes no difference whether the power be developed by the one type of plant or the other, although of course there is a difference in the application of the water and in the type of the implements of power conversion. So far as actual energy is concerned, it makes no difference whether we develop a certain amount of power by allowing ten cubic feet of water per second to fall one foot or by allowing one cubic foot of water per second to fall ten feet. In the following descriptions of power plants, the different conditions outlined above will be illustrated.

St. Lawrence Power Company. ${ }^{2}$ - This plant is of a type in which the head on the wheels is limited, but this deficiency is made up by the use of a large amount of water. It is one of the more recent large power installations in the eastern part of the United States and was at the time of its construction the largest in the United States, with the exception of that at Niagara. The flow of St. Lawrence River is more nearly uniform than that of any large river on the American continent. All of the Great Lakes act as storage reservoirs and their capacity and expanse are so great that the fluctuations of flow that are common to rivers not so regulated are minimized.

In the vicinity of Massena, New York, the St. Lawrence descends over the Long Sault Rapids, the total fall in a distance of eight miles being forty feet. About three miles south of the St. Lawrence, Grasse River runs nearly parallel thereto and enters the former a short distance below the foot of these Rapids. As the channel of Grasse River lies at this point about forty feet lower than that of the St. Lawrence at the head of Long Sault Rapids there are afforded unusually favorable natural conditions for the development of a power plant. All that is necessary for such development

"Abstracted from "Engineering News," Feb. 21, 1901. 
is the cutting of a canal of large capacity across the plateau from the head of Long Sault Rapids and dropping the water over wheels into Grasse River.

The plans for this development as originally laid out, provide for a canal 16,200 feet long, $2261 / 2$ feet wide at the water line, and 25 feet deep, laid on a grade that will provide a flow sufficient for the generation of $75,000 \mathrm{H}$. P. The first step in the construction provides for the utilization of only $35,000 \mathrm{H}$. P., the canal having been excavated more than half its final width. At the end of the canal a dam and power house of monolithic concrete has been constructed. It is one of the largest ever undertaken in this country. The dam is a heavy wall, 8 feet thick at the water level and I 5 feet thick at the floor of the turbine chambers. These cham bers are located on the back of the dam and are separated from each other by walls 6 feet thick, laid at right angles to the axis of the main dam. The chambers between these walls are thirty-two feet in width and each contains three double horizontal turbines mounted on a common shaft. Each shaft pierces the wall of the turbine chamber and enters the dynamo room and upon each is mounted a $5000 \mathrm{H}$. P. generator. Each single turbine has a normal capacity of rono $H$. P. when working at a minimum net head of thirty-two feet. The generators are alternating-current, rotating field machines, developing $5000 \mathrm{H}$. P., each at a potential of 22,000 volts.

At the time the plant was constructed there was little or no market for the power in the vicinity of Massena, and it was the expectation of the promoters of the company that the erection of a power so cheap and efficient at this place would attract the location of sufficient industries, such as pulp and paper, chemicals, etc., to return a profit on the investment. The plant is therefore one of many in the United States constructed in anticipation of market rather than by reason of a market already in existence.

Southern Power Company. ${ }^{3}$-The Southern Power Company, organized June 20, I905, is a good example of a consolidation of water-power interests, which appears to be necessary for the economic development of water powers in many parts of the country. Quite apart from all questions relating to the much discussed problem of industrial consolidation, there is a physical element govern-

"Construction details abstracted from "Engineering Record," May 18, 1907. 
ing the development and utilization of water powers which demands that a large number of powers within certain regions have a common interest. The Southern Power Company, for example, has its field operation in the Piedmont section of the Carolinas, in lower North Carolina and upper South Carolina. Within this section the aggregate available water power is large, but the several units making up that aggregate are comparatively small. The electrical transmission of power over long distances has changed the whole industrial aspect of the matter. Where formerly a water power was utilized at the site and industrial developments proceeded there to the full capacity of that particular power, there was little or no inducement to combine several sites. In other words, the sites were independent in operation. Now, the site of a water power is not likely to be its field of operation, but the power is distributed over a large area. In this large area there is a common demand for power. The market itself constitutes an administrative unit. The demand of the region is a demand in the aggregate and, moreover, it is a demand that must be supplied whether or not the power at any particular point is abundant or scanty. It is a well-known fact that a certain privilege may now produce abundant power, and again may not produce sufficient to meet the normal demands. If the industrial activity of any particular centre is dependent upon that power, it should be clear that the uncertainties of securing power that would arise if only one site were utilized would surely inhibit productive development at that place. When, however, we combine a number of sites on a number of drainage areas, power supply will be comparatively steady. If the power available at a certain site and at a particular time is not sufficient to meet a certain demand, then the available power at a combination of sites may be sufficient.

There is another important consideration: At one point a certain amount of power may be urgently required at a certain time, while at another point the urgent demand may be at a different time, so that in addition to a varying supply, there is a varying demand. This makes it necessary to join together many varying sources of power in order that the supply may be steady, whatever may be the local fluctuations therein. The principle is entirely similar to that in which a company or an individual having large cash assets and urgent calls for money distributes those assets in several banks, with the 
result that in time of financial depression if one bank suspends, there is, in another depository, a sufficient amount of call money to insure the continuance of the business. In other words, the demand for power and the utilization thereof are such that it is fatal to have all the eggs in one basket. This should not be considered as a plea for or a justification of indefinite power consolidation. That subject is not in the province of this paper. It should, on the contrary, be regarded merely as an expression of the requirements imposed by nature's laws.

The original field of the Southern Power Company included ten water-power sites in the basins of the Broad and Wateree Rivers, the aggregate horse power available being about 130,000, of which the largest unit, that at the Great Falls of the Catawba, has a capacity of 30,000 H. P. The other sites are: Rocky Creek, Catawba River, 20,000 H. P.; Fishing Creek, Catawba River, I 5,000 H. P. ; Catawba River at Catawba, I0,000 H. P.; Catawba River at Mountain Island, $5000 \mathrm{H}$. P.; Catawba River at Landsford, I2,000 H. P.; Catawba River at Horseford Shoals, 3000 H. P.; Catawba River at Lookout Shoals, 5000 H. P.; Wateree River, above Camden, S. C., 20,000 H. P., and Broad River at Ninety-nine Islands, I0,000 H. P. All of these powers are of comparatively low head. One of the typical ones, that at the Great Falls of the Catawba, will be described.

The Great Falls of the Catawba cover about eight miles of that river, the fall in that distance being 176 feet. The plan adopted by the Southern Power Company contemplates the utilization of the fall of three plants, which will utilize sixty, seventy-two and forty feet, respectively, the minimum flows at the three plants being 2220 , 2100 and 1950 cubic feet per second, respectively. The resulting powers, allowing eighty per cent. efficiency on the wheels, are approximately $12,000,14,000$ and 7000 , respectively. The arrangement of the middle development, or the one having the head of seventytwo feet, is as follows:

At the head of these falls the river channel is divided into two parts by Mountain Island. Across one of these channels at the head of the Island, an overflow diversion dam is erected which, in times of low water, deflects all of the flow into the other chamel. The main dam at the headworks is located across this channel near the foot of Mountain Island and from thence the power canal con- 
ducts the water nearly one and one-half miles to the tail-race which is located near Rocky Creek, a tributary that enters the Catawba below the fall here immediately utilized. This arrangement was largely adjusted to conform with the natural grade lines there existing, the course of the canal being a natural valley, and a comparatively small amount of excavation was necessary. At the power station, the water is passed over eight wheels and two exciter turbines, through steel penstocks with suitable regulating works. The eight large turbines were required under the contract to furnish $5200 \mathrm{H}$. P. each, at 225 revolutions per minute under a head of seventy-two feet. The discharge from these turbines is conducted into the tail-race between piers supporting the power house.

The Animas Canal Reservoir Water Power Company. ${ }^{*}$-This plant is located in San Juan County, southern Colorado. It is typical of many throughout the country, and especially in the West, which are built in advance of a demand for full capacity of the power privilege. In such places, where a market must be created, it is the usual practice to develop only a part of the power available and to build certain of the appurtenant works of low-cost materials. Thus, the first cost of the plant is reduced to a point at which the small initial business may pay for the fixed charges and possibly return some dividends. In this way, the plant becomes self-supporting while the market grows. From time to time, the temporary structures are replaced by permanent ones and ultimately the full power of the privilege is developed.

The Animas plant is one of the type that utilizes a small amount of water over a high head, the power being recovered on impulse wheels. The water for the first installation was taken from Cascade Creek, a tributary of Animas River. From there it is conducted by a wooden flume about three-quarters of a mile to another tributary, across which is constructed a dam fifty-five feet high and $75^{\circ}$ feet long. This dam is a temporary structure of stone and timber, which will one day be replaced by a masonry structure of nearly twice the present height. From this storage reservoir, the water is conducted by another wooden flume about one and one-quarter miles long to an intake basin, and from this the water is delivered through steel conduit upon Pelton wheels at a static head of about 1000 feet.

The amount of water required by the first installation is eighty-

"Abstracted from "Engineerlug News," of Jan. 4, 1906.

(562) 
seven cubic feet per second and the power developed is from 6000 to 8000 H. P. Future additions to the water supply will provide for an ultimate development of $38,000 \mathrm{H}$. P.

The intake basin, steel conduit, and power-house appurtenances are permanent structures, as distinguished from all that portion of the works above the intake basin. The only change necessary in these lower works in case of increased capacity of plant will be additional installation of conduits, wheels, generators, etc.

The first installation consisted of two Pelton wheels, each of $3000 \mathrm{H}$. P. capacity under normal delivery, but so adjusted that they may be made to develop $4000 \mathrm{H}$. P. each. They are eight feet in diameter and normally operate at 300 revolutions per minute. The electrical equipment consists of two revolving field three-phase sixty-cycle alternators, each of 2250 kilowatts capacity. They afford a voltage of 4000 , which current is transformed to 50,000 by six water-cooled oil transformers, each of $75^{\circ}$ kilowatts capacity. The current is transmitted over three cables, each of which consists of six aluminum, No. 8 B. \& S. wires with a hemp core. The power is transmitted twenty-five miles to Durango and Silverton.

The Snoqualmie Falls Water Power Plant, Washington State." This is a cataract power. Those heretofore described are of a type requiring construction of long canals or flumes. The Snoqualmie Falls power takes advantage of a vertical drop in the channel of that river amounting to about 270 feet. In this respect the privilege resembles that at Niagara. We are accustomed to consider that Niagara Falls develops the greatest cataract head in the country; yet the vertical drop there that has been utilized for power production is only $I_{53}$ feet. The Snoqualmie plant is interesting in many respects.

The usual procedure in installing power plants on such cataracts is to divert the water by means of suitable conduits either in tunnel beneath the cliffs or down the outside thereof to the power house erected above ground at the foot of the cataract. In the present case the water is diverted by suitably arranged headworks into a conduit set in a vertical shaft that descends into the cliff a short distance above the crest of the falls. In other words, a hole is made in the bottom of the river at that point and the water is let down into a chamber excavated in the solid rock to the high water

sAbstracted from "Fngineering News," Dec. 13, 1900. 
level of the pool below the falls. This shaft is ten by twenty-seven feet in cross-section area and 270 feet deep. Beginning at the foot of the shaft and extending horizontally, a chamber 200 feet in length forty feet wide and thirty feet high was excavated. In this chamber the wheels and electrical apparatus are installed. The tail-race consists of a tunnel excavated below the floor of the machinery chamber twelve feet wide and twenty-four feet high and extending outward to the foot of the falls. Thus, the entire generating plant is concealed and the only evidence to the casual observer of the existence of such a plant is the structure at the headworks and the opening of the tail-race tunnel at the foot of the cliff. The conduit that conducts the water from the surface extends along the top of the machinery chamber and from it branches are taken leading to the wheels. This conduit or penstock is a steel pipe, seven and one-half feet in diameter. The branches leading therefrom to the wheels are fitted with gate valves weighing 23,000 pounds each and were at the time of installation the largest in the world.

The generating plant consists of four electrical generators, each driven by a Doble water motor of $2500 \mathrm{H}$. P. capacity. This motor consists of a shaft carrying tangential jet wheels and the water is conducted under pressure against the flanges by two nozzles to each wheel, these nozzles being so placed that the two jets of water are delivered against the wheel flanges at right angles to each other. Each wheel unit weighs about roo,ooo pounds. The electrical generators are of 1500 kilowatt capacity each. They are of the revolving armature type, delivering a three-phase current at Iooo volts, 7200 alternations. The transformer house is above ground at the head of the shaft. The current is received at an initial voltage of 1000 and is raised to 30,000 . The power is transmitted to Seattle, Tacoma and Everett, at distances of thirty-two, forty-four and thirty-five miles, respectively. The transmission circuits are of stranded aluminum cables, and this was the first instance of the use of this metal in long-distance transmission. These wires stop at the city limits of Seattle, Tacoma and Everett, and copper is used beyond these points.

The ultimate capacity of the plant is about $100,000 \mathrm{H}$. P., and the flow of the river at its lowest stage is about 1000 cubic feet per second. In order to accomplish the ultimate power capacity, it will be necessary to construct reservoirs in the Cascade Range at the 
head of Snoqualmie River and sites for such reservoir systems are abundant. Construction on this plant was begun April 17, r898, and it was put into operation on July 3I, I899.

Conclusion. A few of the general principles governing waterpower development have been reviewed. Some of the broader considerations relating to the political economy of the production and use of mechanical energy have been cited. There is much more that might be said. The main purpose of the paper has been to emphasize the fact that the water powers of this country have a higher ultimate significance than is generally conceded to them, and that they are certain to have a dominating effect upon the material progress and the integrity of this Republic. If we are to place ourselves in an economic position in which we may finally prevail as a world power, our point of view regarding fuel and water power must be changed, and our policies must be altered so that we may wisely prepare to use the vast power resources which we are now neglecting. 